\title{
ПРЕВОЗМОЖЕНИЕ ЧЕЛОВЕКА
}

Аннотация. В статье речь идёт о содержании замечательной монографии В.И. Самохваловой «Сверхчеловек: образ, метафора, программа» (М., 2015), в которой автор на значительном философском материале стремится обосновать ницшеанскую идею сверхчеловека. Эта проблема рассмотрена ею в традиционных учениях, в различных религиозных системах, в мифах и современных культурных представлениях. Действительно, тема имеет огромную предысторию. Вместе с тем она обросла многими стереотипами, вольными толкованиями, различными смыслами. В наши дни сам сверхчеловек понимается диаметрально по-разному - от идеи совершенствования человека до его замены созданием на кремниевом носителе.

Автор опирается на обширную философскую традицию, от древних мистов до современного трансгуманизма. Использован герменевтический метод, позволяющий обнаружить скрытые смыслы в давно известных философских текстах.

Ещё совсем недавно относительно человека звучали только погребальные мотивы. Философы с упоением описывали его кончину не только в виде темы философской антропологии, но и в качестве мерцающей антропологической данности. Человек умер не только как животное, но и как историческое создание. Человек стал множественным и растворился во всем, что его окружало - природе, обществе, технологиях. Философская антропология в отличие от других областей метафизического знания утратила свой предмет. Oт человека остались лишь следы и метки. Однако постепенно тема живого, телесного и почти бессмертного человека стала обнаруживаться даже в постмодернистской философии.

Ключевые слова: человек, сверхчеловек, Ницше, иномерный человек, антропологическая мера, философия, смысл, страдание, духовность, философская антропология.

Abstract. This article reviews a remarkable monography by V. I. Samokhvalova "Superhuman: image, metaphor, and program" (M., 2015), in which the author based on the significant philosophical material attempts to substantiate Nietzsche's idea of Übermensch (superhuman). This problem is examined in traditional doctrines, various religious systems, myths, and modern cultural perceptions. It is evident that this topic has an outstanding background story, but at the same time it attained many stereotypes, free interpretations, and various meanings. Today, the notion of superhuman could be understood very differently - from the idea of perfection of a human, all the way until human brain replacement with a silicon chip. The author bases on an extensive philosophical tradition, including the modern transhumanism, and also applies hermeneutic method that allows revealing hidden meanings in the well-known philosophical texts. Even recently, with regards to a human, we could hear exceptionally funeral motifs. Philosophers were ecstatically describing the human demise not only as a topic of philosophical anthropology, but also as a flickering anthropological given. Human died not only as an animal, but also as a historical creature, human dissolved in everything that surrounding him - nature, society, technologies. However, the topic of a living, bodily, and almost immortal human gradually became evident in even post-modernistic philosophy.

Key words: Human, Superhuman, Nietzsche, Others-dimensional human, Anthropological human, Philosophy, Meaning, Suffering, Spirituality, Philosophical anthropology.

Рецензия на книгу:

Самохвалова В.И. Сверхчеловек: образ, метафора, программа. М.: Ваш формат, 2015. 440 с.

Пока осторожно, через критические расчёты с классической философской антропологией вновь обозначился интерес к потомку Адама. Тема тризны уступила вековечному сюжету - человек в своём невиданном совершенстве, в своей вершинной мощи и завлекательности. Сначала Ю.В. Шичанина усильным напряженным постоянством (докторскую диссертацию об «иномерном человеке» пришлось защищать дважды) объявила о парадоксе антропологической меры. «И всякий раз, когда философия, - писала она, - предпринимает попытку познать человека, она вынужденно обращается к обсуждению его потенциальных возможностей и к полаганию его пределов. Мысль о том, каким человеку уготовано когда-нибудь быть, в конечном итоге уравновешивается рассуждениями о том, 
каким ему никогда не стать, и разные варианты промежуточных версий уплотняют пространство философской антропологии» [1, с. 3].

Однако обозначенные Ю.В. Шичаниной пределы, каким человеку не быть, неожиданно захлестнула волна не перековки человека, а сотворения его заново. Началась мучительная выбраковка человека, присущих ему свойств, его заведомо порочной природы, его разрастающей деструктивности. Одним словом, «шагнула дерзко за предел нас опьянившая свобода». Ветхому Адаму пришел конец. Заговорили о кибернавте, несущем будто бы новые экзистенциальные смыслы. Притягательной стала тема тотального превозможения человека. Оказалось, что человек никогда не был доволен собой. Уже древние мисты усматривали возможности и ресурсы человеческого преображения.

Эта тема привлекла внимание и В.И. Самохваловой. Её очередная монография в целом - блестящий образец монографического исследования. Автор не только достаточно эрудирован. Вера Ильинична обладает ясной логикой и хорошо владеет расчленяющей и упорядочивающей мыслью. Она прикоснулась к ницшеанской теме «сверхчеловека». Ж. Делёз предупреждал в своё время, чем угрожает этот дерзкий замысел. Чтобы понять Ницше, нужно испытать на себе первориск творца, а не делать его объектом «незаинтересованного» созерцания. В.И. Самохвалова не осталась на берегу, не заглянула в психическое расстройство. Но проявила мужество и готовность «выстрадать» Ницше.

Что, вообще говоря, угрожает этой значимой теме - сверхчеловек? Её легко можно растворить в потоке бесчисленных и разносмысловых сюжетов. В качестве примера такой «дисперсности» можно назвать недавнюю монографию Д.А. Беляева [2]. Автор рецензируемой рукописи взял на себя серьёзные обязанности. Он решил проследить историю концепта «сверхчеловек». Естественно, он не ограничился при этом лишь ницшеанской идеей. В поле его интереса вошли самые разнообразные взгляды мыслителей разных ориентаций. Он анализирует едва ли не весь спектр значимых дискурсов о сверхчеловеке конца XIX - начала XX вв. Таким образом, проблема обрела неожиданную поливариантность. Но если «сверхчеловек» во всём, то его по сути дела и нет.

Скажем сразу, тема реализации тех или иных возможностей человека не обязательно пристёгивается к проблеме «сверхчеловека». Как бы ни пришлось в этом случае включать в данное русло любое напряжение философской, художественной или этической мысли. Тема нуждается в огранке. Речь идёт по сути дела об особой явленности другого человека, а не того, кто ведёт свою родословную от Адама. Этот вектор включает в себя три варианта каким может стать человек, если он способен реализовать все свои ментальные, психологические, нравственные и трансцендентные ресурсы. Это первый смысл понятия «сверхчеловек», уточнённый В.И. Самохваловой. В этом варианте человек не утрачивает свой идентичности, собственной человеческой природы, которая неустанно проявляет себя в его природном и историческом бытии. Но он достигает множества идеальных качеств.

Однако понятие «сверхчеловек» может обозначать и другое: творение, которому прежний человек уступит своё место. В этом смысле пролегает граница между обезьяной и человеком, между человеком и постчеловеком («хьюманом», кибернавтом). Важно при рассмотрении темы не упустить и ещё один вариант проблемы - каким человек может стать и каким он не станет никогда, поскольку никто пока не обсуждает всерьёз призыв Э. Фромма «Будьте как боги». К божественному можно тянутся с немыслимым азартом. Но люди не боги.

В.И. Самохвалова рассуждает о правомерности и актуальности самой темы. Общество становится безликим, социальность испытывает мощные подземные толчки. Сам замысел о человеке становится бессмыслицей. Массовая культура обнаруживает себя как прелюдия к отупению и дикости. В этом смысле идея сверхчеловека, возможно, всегда (как и в ницшеанском варианте) рождалась как антитеза никчёмности существования, безмыслия и духовной пустоты. Мы хотим вернуть сияние слову «человек», но в то же время отрекаемся от него. «Потому что он живой человек, способный к многоуровневому поступательному развитию, он обладает человеческой свободой, т.е. способен к нейтрализации принуждений природы и общества, к человеческому сопротивлению тупой инерции, инволюции в себе, варварству в обществе, что он может - и должен - работать против деградации, изживать в себе негатив и тенденции к нравственному и интеллектуальному опрощению, духовному распаду» [3, с. 19].

0 ком это - о человеке или сверхчеловеке? Мне не очень понятно, почему человек должен стать сверхчеловеком, если он реализует исстари обозначенные им цели? Может быть, мы уже разуверились в том, что этот человек давно уже обнаружил собственное бессилие сохранить «специфически человеческое» и тогда, как говорится, без сверхчеловека - ну, никак. Но в этом случае мы смыкаемся с рассуждениями трансгуманистов о тотальной перекодировке человека. Может быть, программа сверхчеловека - это программа 
постановки сверхзадач, открывающих сверхвозможности и реализуемых человеком? [3, с. 24]. Но как только мы переходим от общих заклинаний, рождается масса конкретных вопросов. К примеру, гений - это сверхчеловек или носитель одной превосходящей меры? Наряду с гением Н.А. Бердяев считал аскета весьма значимым антропологическим персонажем. Это - сверхчеловек? Какого человека мы хотим получить в результате осуществлённой программы «супермена»? Прежде всего, умного, интеллектуально одарённого, поднимающего человечество на невиданные высоты мысли? Или, прежде всего, религиозного, помогающего человечеству проникнуть в трансцендентные ярусы мира? Образцово мышечного? Поражающего нас великолепием человеческого тела? Физиологически прекрасно уравновешенного? Альтруиста? Эгоиста? Тонко чувствующего красоту и влекущего нас в мир эйдетических образов? Вооружённого критическим мышлением, что предполагает автономность личности?

Однако выдержит ли социальность сонмище нестандартно ведущих себя индивидуальностей? Верно ли, что человек, который одолевает в себе инволюцию, отдаётся во власть безучастной эволюции? Хотя если эволюция может быть только сознательной, как полагал П.Д. Успенский, тогда, конечно... Но ведь в этом смысле это уже и не эволюция как таковая, а катапультирование в неизвестность, хотя и по сознательному расчёту.

В этом случае все акценты расставлены. Речь уже идёт не о замысле человека, а о вымысле его. Это, считал А. Белый, более реальная грёза. Тогда правомочна и свободная игра мысли. Сама по себе благородна задача выразить глубину идеи Ницше, критически отнестись к попыткам её «усыновления» постмодернистами. Построение образа сверхчеловека - это парадигма преодоления существующей реальности. Но и сторонники квантового мышления стремятся к новым образам действительности.

Хотел бы весьма почтительно отнестись к тому перечню исследовательских задач, которые формулирует В.И. Самохвалова. Она пишет: «Сама по себе постановка данной проблемы предполагает обязательное обращение к рассмотрению, а также требует современной научно-философской разработки следующих, необходимо «сопутствующих» вопросов: о природе человека и его идентичности; о понимании человеческой «нормы» и способов (видов, параметров) её “превосхождения” в человеке; о самих целях её превосхождения; о цели и смысле самой человеческой жизни как таковой; о направленности и цели человеческой эволюции и самой возможности её направленного развития, а также о возможности и надобности "ускорения" её или усовершенствования, о самом разомкнутом (в метафизику) содержании, наконец, того “континуума", который мы называем “сверхчеловеком" и т.д.» $[3$, с. 62].

Интересно поставлен в монографии вопрос о градациях сверхчеловеков. Затем нам предлагают войти в сферу обликов сверхчеловека? Вслед за Батаем В.И. Самохвалова отмывает Ницше от нацистской грязи. Нет оснований демонизировать образ Ницше. Однако нет смысла отвлекаться от тех следствий, которые вытекают из учения немецкого философа.

Можно, к примеру, сказать: хотим разного, пусть в сверхчеловеке будет всё... Но это невозможно. Нужно выбирать. Нельзя, допустим, получить человека одновременно рационального и высокодуховного, образцово мышечного и религиозного... Когда в романах нам предлагают модели нового человека, то сразу рождается ужас перед этим типом - либо гения зла либо героического болвана. Ни ученые (психологи, социологи), ни моралисты, ни философы не способны создать модель идеального человека, который достоин технического воспроизводства. А, может быть, сверхчеловек - это мечта о торжестве социального конструирования, столь модного в современной литературе? Мания прописывания обществу идеальных конструктов?

Впрочем, В.И. Самохвалова легко сводит концы с концами. Она пишет: «Человек в определённом смысле может быть истолкован как форма (выступания), которая может изменяться, вмещая новое содержание; сверхчеловек выступает как результат движения вверх по отношению к исходному человеку» [3, с. 33]. Значительный и ценный материал содержится в книге В.И. Самохваловой, когда речь заходит о Ницше. Цитат и различных оценок ницшеанского наследия в книге много.

Размышления о Ницше - самое интересное в монографии. Вера Ильинична увлечена им. Она хочет понять философа через его страдание, а не через его вербальную установку. Ради идеи сверхчеловека она пытается соединить его даже с христианством. Нужны особые интеллектуальные усилия, чтобы приписать автору «Антихристиана» гостеприимное отношение к этому учению. У Веры Ильиничны Ницше в одной связке с В.С. Соловьёвым. Оказывается оба они стремились объяснить для себя смысл христианской религии, выразить дух христианства. Отвага В.И. Самохваловой впечатляет. Автор мобилизует идеи русских философов. И что же? Оказывается, «ницшевская идеология сверхчеловека по духу, а не по факту, и в этом 
случае не столь уж далека от исходного христианства как достаточно суровой и решительной религии» [3, с. 275].

Идеальных порывов у Ницше много. Он, в частности, хотел избавить человека от иррационального страха. Но, пожалуй, только усилил это чувство: когда человек долго смотрит в бездну, бездна начинает смотреть на него. После этих слов Ницше мне лично не страшна уже никакая пропасть. Но чтобы быть ницшеанцем, нужно стать заколдованным этой бездной.

В.И. Самохвалова отчаянно очищает Ницше от разных, незаслуженно прилипших к нему суждений. Смерть Бога, оказывается, возвестил Гегель, а вовсе не Ницше. Бог, следовательно, если и был убит, то не философом, а позорными людьми. А что же он сам? «Ницше поглощает мысль о сверхчеловеке, способном к освобождению от власти случая и рока. Его Сверхчеловек говорит «да» жизни, принимает её со всем её содержанием и уверен в своей способности усовершенствовать, улучшить её. Ницше хочет показать возможность пробуждения человека к новой благородной жизни (собственно человеческой, как должно быть), но отдаёт себе отчёт в том, что пока к этому готово меньшинство, и это меньшинство должно направлять остальным своим примером» [3, с. 284]. Хороши здесь две фрейдистских оговорки. Сверхчеловек зовёт нас к собственно человеческой жизни. И, оказывается, не все её достойны.
И второе - что это за «меньшинство», готовое, по мысли Ницше, уже дотянуться до сверхчеловека. Крути, не крути, а идея избранности у Ницше созвучна современному элитизму: «В современной социальной структуре, - рассуждает А.П. Люсый, - элиты озабочены не столько руководящей и направляющей ролью, сколько ускользанием от общей судьбы, в чём и заключается сама суть элитарного успеха. Имеет место массовый провал в социальной сознательности и воображении. “С ошеломляющей предсказуемостью” поминаются новые пароли для опознания своих: "раса гендер - класс", которые по разному фиксируют крах солидарности. Предательство демократии заключается в том, что она отказалась от противостояния любым формам двойного стандарта и отказалась от усилий поднять общий уровень компетентности, довольствуясь тем, чтобы обеспечить компетентность класса, играющего роль опекуна и попечителя, нагло присваивающего себе право надзирать за всеми остальными» [4, с. 1700].

Монография В.И.Самохваловой поражает оригинальностью мысли, доказательностью собственных взглядов, основательностью проработки материала. Но лично мне дорог другой Ницше - не припудренный, не отбеленный, а живой и заразительный в своём безумии. И не хочу «аз грешный» быть сверхчеловеком. Лучше я останусь с шекспировским Гамлетом: «Он человек был в полном смысле слова».

\section{Список литературы:}

1. Шичанина Ю.В. Человек «иномерный». Парадоксы антропологической меры. Ростов-на-Дону: Изд-во Рост. пед. у-та, 2006. С. 3.

2. Беляев Д.А. История определения сверхчеловека. Липецк: ЛгпУ, 2016. 186 с.

3. Самохвалова В.И. Сверхчеловек: образ, метафора, программа. М.: Ваш формат, 2015. С. 19, 24, 33, 62, $275,284$.

4. Люсый А.П., Нилогов А.С. Текстологическая концепция русской культуры (беседа А.П. Люсова и А.С. Нилогова) // Философия и культура. 2015. № 11. С. 1699-1723.

5. Синеокая Ю.В. Проблема сверхчеловека у Соловьева и Ницше // Вопросы философии. 2002. № 2. С. 43-60.

6. Синеокая Ю.В. Рубеж веков: русская судьба Сверхчеловека Ницше // Фридрих Ницше и философия в России: сб. ст. СПб.: РХГИ, 1999. С. 58-74.

7. Синеокая Ю.В. Философия Ницше и духовный опыт России (конец XIX - начало XXI веков): Дисс. ... докт. филос. наук. M., 2009.

\section{References (transliterated):}

1. Shichanina Yu.V. Chelovek «inomernyi». Paradoksy antropologicheskoi mery. Rostov-na-Donu: Izd-vo Rost. ped. u-ta, 2006. S. 3.

2. Belyaev D.A. Istoriya opredeleniya sverkhcheloveka. Lipetsk: LGPU, 2016. 186 s.

3. Samokhvalova V.I. Sverkhchelovek: obraz, metafora, programma. M.: Vash format, 2015. S. 19, 24, 33, 62, $275,284$.

4. Lyusyi A.P., Nilogov A.S. Tekstologicheskaya kontseptsiya russkoi kul'tury (beseda A.P. Lyusova i A.S. Nilogova) // Filosofiya i kul'tura. 2015. № 11. S. 1699-1723.

5. Sineokaya Yu.V. Problema sverkhcheloveka u Solov'eva i Nitsshe // Voprosy filosofii. 2002. № 2. S. 43-60.

6. Sineokaya Yu.V. Rubezh vekov: russkaya sud'ba Sverkhcheloveka Nitsshe // Fridrikh Nitsshe i filosofiya v Rossii: sb. st. SPb.: RKhGI, 1999. S. 58-74.

7. Sineokaya Yu.V. Filosofiya Nitsshe i dukhovnyi opyt Rossii (konets XIX - nachalo XXI vekov): Diss. ... dokt. filos. nauk. M., 2009. 